Quant à la langue adoptée pour la bibliographia, M. Pelseneer proposa les cinq langues suivantes: anglais, allemand, français, italien, espagnol. Pour les publications non rédigées dans l'une de ces langues une traduction du titre et du résumé sera donnée dans l'une de ces cinq langues. L'opinion des membres présents s'est montrée favorable à cette proposition.

\title{
COMMISSION 6 (TELEGRAMS)
}

\author{
President: Dr H. Spencer Jones. \\ Secretary: Dr LouIs C. Green.
}

The Commission approved the report of the Director of the Bureau and asked for an annual grant of r200 gold francs to the Bureau of Astronomical Telegrams until the next meeting of the Union.

\section{COMMISSION 8 (MERIDIAN ASTRONOMY)}

\author{
PRESIDENT: Dr J. Jackson. \\ SeCRETARY: Dr G. van HeRK.
}

Commission 8 of meridian astronomy met on Friday, August 5 , at $10^{\mathrm{h}} 3 \mathrm{o}^{\mathrm{m}}$.

On request of the President some supplementary remarks were made on the subjects mentioned in his report. Since the President's report was written a few more reports have come in, viz. from Pulkovo, stating that fundamental work is still carried on and that the trials of an automatic registration of star transits with a photoelectric cell connected with the Bamberg instrument are successful for stars down to the magnitude 5.7; from Tokyo, saying that fundamental stars are being observed in connection with the bright minor planets; from Prof. Leuschner a paper by $\mathrm{Mr}$ Herrick on standard coordinates on photographic plates and the transformation from one plate to another.

Prof. Boss remarked that the proper motions from the Albany General Catalogue give consistent results for solar motion with regard to a subdivision to types and magnitudes. The hope was expressed that in future the calibration of the barometers and thermometers used, will be given in the introductions to observational results in order to facilitate computations on refraction researches. Dr Jackson remarked that the Leiden azimuth instrument gave declinations free from refraction. A statement was made that plans for improving the Leiden instrument for determining declinations from azimuth observations will be realized in the near future. The differences Leiden minus G.C. declinations show the same general line as is the case with the P.G.C. declinations, the numbers being only about $0^{\prime \prime} \cdot 30$ smaller.

$\operatorname{Dr} A$. Lambert gave an account of the present state of the work done in France and Belgium on faint galactic stars. From the 4800 stars in all, about Iooo have been observed now. The hope is expressed that some southern observatory will join in the work.

The Astronomer Royal gave an account of the work being done in Greenwich with the new transit instrument. If one uses the pivot telescope the lens should be 